\title{
A risk assessment methodology to evaluate the risk failure of managed aquifer recharge in the Mediterranean Basin
}

\author{
Paula Rodríguez-Escales ${ }^{1,2, *}$, Arnau Canelles ${ }^{1,2, *}$, Xavier Sanchez-Vila ${ }^{1,2}$, Albert Folch ${ }^{1,2}$, Daniel Kurtzman ${ }^{3}$, \\ Rudy Rossetto ${ }^{4}$, Enrique Fernández-Escalante ${ }^{5}$, João-Paulo Lobo-Ferreira ${ }^{6}$, Manuel Sapiano ${ }^{7}$, Jon San-Sebastián ${ }^{5}$, \\ and Christoph Schüth ${ }^{8}$ \\ ${ }^{1}$ Dept. of Civil and Environmental Engineering. Universitat Politècnica de Catalunya, Barcelona, Spain \\ ${ }^{2}$ Associated Unit: Hydrogeology Group (UPC-CSIC) \\ ${ }^{3}$ Institute of Soil, Water and Environmental Sciences, The Volcani Center, Agricultural Research Organization, \\ Rishon LeZion, Israel \\ ${ }^{4}$ Institute of Life Sciences, Scuola Superiore Sant'Anna, Pisa, Italy \\ ${ }^{5}$ Empresa de Transformación Agraria (TRAGSA), R\&D department, Madrid, Spain \\ ${ }^{6}$ Laboratorio Nacional de Engenharia Civil, Lisbon, Portugal \\ ${ }^{7}$ Energy and Water Agency, Luqa, Malta \\ ${ }^{8}$ Institute of Applied Geosciences, Technische Universität Darmstadt, Darmstadt, Germany \\ *These authors contributed equally to this work.
}

Correspondence: Paula Rodríguez-Escales (paula.rodriguez.escales@upc.edu)

Received: 9 January 2018 - Discussion started: 16 January 2018

Revised: 12 May 2018 - Accepted: 15 May 2018 - Published: 8 June 2018

\begin{abstract}
Managed aquifer recharge (MAR) can be affected by many risks. Those risks are related to different technical and non-technical aspects of recharge, like water availability, water quality, legislation, social issues, etc. Many other works have acknowledged risks of this nature theoretically; however, their quantification and definition has not been developed. In this study, the risk definition and quantification has been performed by means of "fault trees" and probabilistic risk assessment (PRA). We defined a fault tree with 65 basic events applicable to the operation phase. After that, we have applied this methodology to six different managed aquifer recharge sites located in the Mediterranean Basin (Portugal, Spain, Italy, Malta, and Israel). The probabilities of the basic events were defined by expert criteria, based on the knowledge of the different managers of the facilities. From that, we conclude that in all sites, the perception of the expert criteria of the non-technical aspects were as much or even more important than the technical aspects. Regarding the risk results, we observe that the total risk in three of the six sites was equal to or above 0.90 . That would mean that the MAR facilities have a risk of failure equal to or higher than $90 \%$ in the period of 2-6 years. The other three sites
\end{abstract}

presented lower risks $(75,29$, and $18 \%$ for Malta, Menashe, and Serchio, respectively).

\section{Introduction}

Water scarcity, the chronic lack of sufficient quality water to supply a specific area is one of the major global challenges. In the Mediterranean Basin, due to low overall precipitation and a pronounced irregularity of rainfall events, it has direct impacts on economic sectors that depend on water, such as agriculture, tourism, and related industries (Fader et al., 2016; Maliva and Missimer, 2012; NavarroOrtega et al., 2012; Stanhill et al., 2015). Besides this, the population in the Mediterranean area increased from 81 million in 1960 to 145 million in 2011 (European Environment Agency, 2015), placing additional stress upon existing water resources. Moreover, the Mediterranean Basin is one of the most sensitive regions of the world to climate changes resulting from human activities; according to the latest IPCC projections, average precipitation could decrease by more than 
$10 \%$, with a larger decrease in summer and in the southern areas (Pachauri et al., 2014).

At the same time, large water quantities are lost to the Mediterranean Sea as surface runoff and discharges from rivers, treated and untreated wastewater, or excess water from various sources during periods of low demand. These alternative water sources can potentially help to increase water availability, both in general terms and in periods of high demand, therefore improving water security. The main factors hindering the effective use of such waters are related to concerns about water quality and the lack of sufficient low-cost intermediate storage options. In principal, large storage capacity is available in shallow aquifers, mostly in thick unsaturated zones or in already depleted overexploited aquifers. Managed aquifer recharge (MAR) takes advantage of this available storage.

MAR is defined as the intentional infiltration of water into aquifers with the purpose of either later recovering that water for different uses (agricultural, industrial, or urban) or obtaining an environmental benefit (Dillon et al., 2009). MAR includes a range of recharge options (surface or subsurface) and water sources (natural, reclaimed, or desalinated) (Bouwer, 2002; Dillon, 2005; Dillon et al., 2009; Maliva and Missimer, 2012; Sprenger et al., 2017). Furthermore, MAR can involve different engineering solutions, among them are infiltration ponds, surface spreading, bank filtration, and wells infiltrating into either the unsaturated or the saturated zones. In addition, water quality can be improved through MAR due to the combination of chemical and biological reactions during transport of the infiltrated water. Water can either be recovered at the point of infiltration (ASR - aquifer storage and recovery) or some distant downgradient (ASTR - aquifer storage, transport, and recovery). The infiltrated water can enable hydraulic control of an aquifer, e.g., to prevent seawater intrusion, aid aquifer quality recovery (amelioration of the groundwater quality), or sustain groundwater-dependent ecosystems such as wetlands or marshes. Altogether, MAR links water reclamation, water reuse, and water resources management.

Due to these beneficial effects, MAR is now widely regarded as a useful tool to ensure a safe and good quality water source for the increasing demand. However, to guarantee the success of any MAR project, some essential elements need to be considered (Dillon et al., 2009): (i) an adequate source of water for recharge, (ii) a suitable aquifer to store and recover water, (iii) available land to construct the facilities, (iv) a sufficient demand for the recovered water, and (v) the capability to efficiently manage such a project. If any of these elements fail, a MAR project is usually not viable. However, the listed factors seem to involve infrastructural and management aspects only, and ignore legal, social, economic, and political constraints that can significantly entangle MAR application, eventually leading to failure of the project as a whole. In addition, the analysis of the potential success of a MAR project should account for both the initial set up of installation and also for the potential issues that will arise during its operation (European Community, 2000).

The most common identified technical risks for MAR facilities (e.g., Asano and Cotruvo, 2004; Gale et al., 2006; Leviston et al., 2006; Maliva and Missimer, 2012) are those related to the following: (i) the operation of the facility (low recovery rates, clogging, mechanical or structural damage, low storage efficiency, high energy consumption); (ii) water quality, either recharged or extracted; (iii) hydraulic engineering impacts, such as rock fracturing, subsidence, or host porous media dissolution; and (iv) environmental impacts, including reduced water outflow to springs and rivers, proliferation of pests and odors, and the impact on aquiferdependent ecosystems.

MAR facilities can also be affected by legal, social, economic, and political issues, which increase the risk of failure, meaning that the facility would not begin or continue operation. Therefore, a full and complete risk assessment must encapsulate all relevant constraints and their confidence levels at a given time and projected into the future. In addition, risk evaluations might include the implementation of measures to control risk by either diminishing the probability of occurrence of a given hazard or by reducing and correcting its effects if they eventually occur.

The implementation of a MAR facility is therefore subject to a relatively high degree of uncertainty (Bouwer, 2003; Dillon et al., 2009). Uncertainty can be managed using probabilistic risk assessment (PRA), a concept used in various fields of science and engineering. Risk is defined here as the probability of an undesired outcome to happen (evaluated in terms of percentage of occurrence) that causes a damage (directly, i.e., breakage of pipes, or indirectly, i.e., perception of effectiveness) to the recharge system and therefore causes a failure during operation or design of the MAR facility. Different definitions for risk in MAR are available in the literature; Maliva and Missimer (2012) defined it as the feasibility (technical and economic) to meet regulatory requirements for aquifer recharge.

Several methods are available for risk evaluation. One such method is the development of "fault trees", already used in engineered systems (Bedford and Cooke, 2003; Vesely et al., 1981). Since MAR systems comprise a mixture of natural and engineered components, this approach has received some attention in the hydrological community (e.g., Bolster et al., 2009). The basic idea of PRA based on fault trees (PRAFT) is to take a complex system, difficult to be handled as a whole, and to divide it into a series of quasi-independent simpler events that are manageable individually (i.e., basic events). Once probabilities of occurrence of basic events are computed, they are recombined in a systematic manner to provide the overall risk assessment of the system as a whole. Examples of applications of PRA-FT in hydrogeology include De Barros et al. (2011, 2013) and Jurado et al. (2012).

Although some approaches to evaluate the risk of a MAR system have been developed (Assmuth et al., 2016; 
Ayuso-Gabella et al., 2011; Dillon et al., 2016; Ji and Lee, 2016, 2017; Juntunen et al., 2017; Page et al., 2010; Toze et al., 2010), comprehensive studies that integrate both nontechnical and technical factors are absent (Nandha et al., 2015). In this study, we (i) precisely present an integrated PRA-FT that is applicable for a general MAR facility and (ii) apply it to six different MAR facilities that were part of the EU FP7 project MARSOL, located in five different Mediterranean countries: Portugal (1), Spain (2), Italy (1), Malta (1), and Israel (1). To achieve these goals, basic events that can lead to MAR failure were first compiled based on a literature review of $51 \mathrm{MAR}$ facilities worldwide, and also on data from the MARSOL project. The next step was the development of six individual fault trees for the tested sites, and assigning probabilities of occurrence for these events. Finally, we used the six sites to compare the different realities and to test the relative relevance of technical versus non-technical events.

\section{Literature review - events involved in MAR failure}

MAR failure is defined as the need to stop operation of the facility. This failure can be either complete or partial. Partial failure means that it is possible to mitigate the problem in a short period of time so that the facility can be put back to operation, where complete failure implies that the facility needs to undertake significant changes and reparations in order to work again (or even not working ever again after the failure). In this paper, the failures exposed are considered as partial failures due to the fact that none of the MAR facilities reviewed in the literature permanently stopped working after those failures occurred.

Basic events that can lead to MAR failure were compiled based on a literature review of the problems encountered by different facilities around the world (Aiken and Kuniansky, 2002; Alazard et al., 2016; Assmuth et al., 2016; Bhusari et al., 2016; Chaoka et al., 2006; Flint and Ellett, 2005; Masetti et al., 2016; Murray and Ravenscroft, 2010; Petersen and Glotzbach, 2005; Schneider et al., 1987; Izbicki et al., 2006; Sultana and Ahmed, 2016; Tredoux et al., 2009; Tredoux and Cain, 2010; Tripathi, 2016). We revised 51 MAR facilities at 47 sites (some sites involved more than one facility) located in different countries and climatic conditions worldwide: Australia, Belgium, Botswana, China, Finland, France, Germany, India, Israel, Italy, Jordan, Namibia, South Africa, Spain, Tunisia, and USA. We classified the facilities according to infiltration typology: deep wells (24), surface infiltration (22), and vadose infiltration (5). A summary of the facilities and details can be found in Sect. S1 of the Supplement.

We then sorted the main causes of MAR failure in terms of frequency of appearance for deep wells and infiltration basins (Fig. 1). Furthermore, we classified these problems into technical and non-technical problems and sub-classified them into different categories. The technical problems with the most occurrence were clogging and the presence of nutrients; they were present in 40-50\% of the reviewed facilities (Fig. 1) and in all types of MAR facilities. Three types of clogging were reported: being in order of decreasing importance, biological, physical, and chemical. On the other hand, the nutrient issues were mainly related to the presence of nitrogen and phosphorus in the recharge water, mostly associated with the use of insufficiently treated reclaimed or surface water, with high nutrients levels, for recharge.

In general terms, quality and infiltration issues were the main aspects that limited the viability of MAR facilities. In fact, the six first technical reasons of MAR failure were the same in all facilities: clogging, nutrients, metals, droughts, low infiltration rate, and salinity-sodicity. This can be explained because MAR facilities are often in semi-arid countries were droughts (a main problem from the quantitative point of view) are common. Quantity issues were seldom relevant, and only in infiltration basins. Civil work failures and natural hazards were rarely reported as problems.

Regarding the non-technical aspects, they were classified into four groups: legal constraints, economic constraints, social unacceptance, and governance-related problems. The actual issues identified in the MAR facilities revised were thus related to cost (maintenance and installation of the MAR facility), legal aspects (mainly sanitary issues for the infiltrated or the reclaimed waters), and local constraints (land permissions and urban planning issues).

\section{Methodology - development of the fault trees and risk evaluation.}

The methodology used consisted of four steps, modifying the scheme followed by Bedford and Cooke (2003): (1) the definition of the concept of system failure and the identification of the basic events that would potentially result in such failure; (2) construction of the fault tree depicting the combination of events, seeking the combination of all possible events that may contribute to system failure (where all events should be as independent from each other as possible); (3) developing a probabilistic representation of the fault tree using Boolean algebra; and (4) computing the individual probabilities of event occurrence using conservative approaches and individual event probabilities and upscaling to calculate the global risk of the facility.

\subsection{Failure definition and identification of basic events}

The first step was the identification of the basic events that can produce a failure in a general MAR facility by reviewing the literature (Sect. 2) and, as a second step, by an extension based on the knowledge and the experience of the facility managers. Failure was based on the operation stage, which 

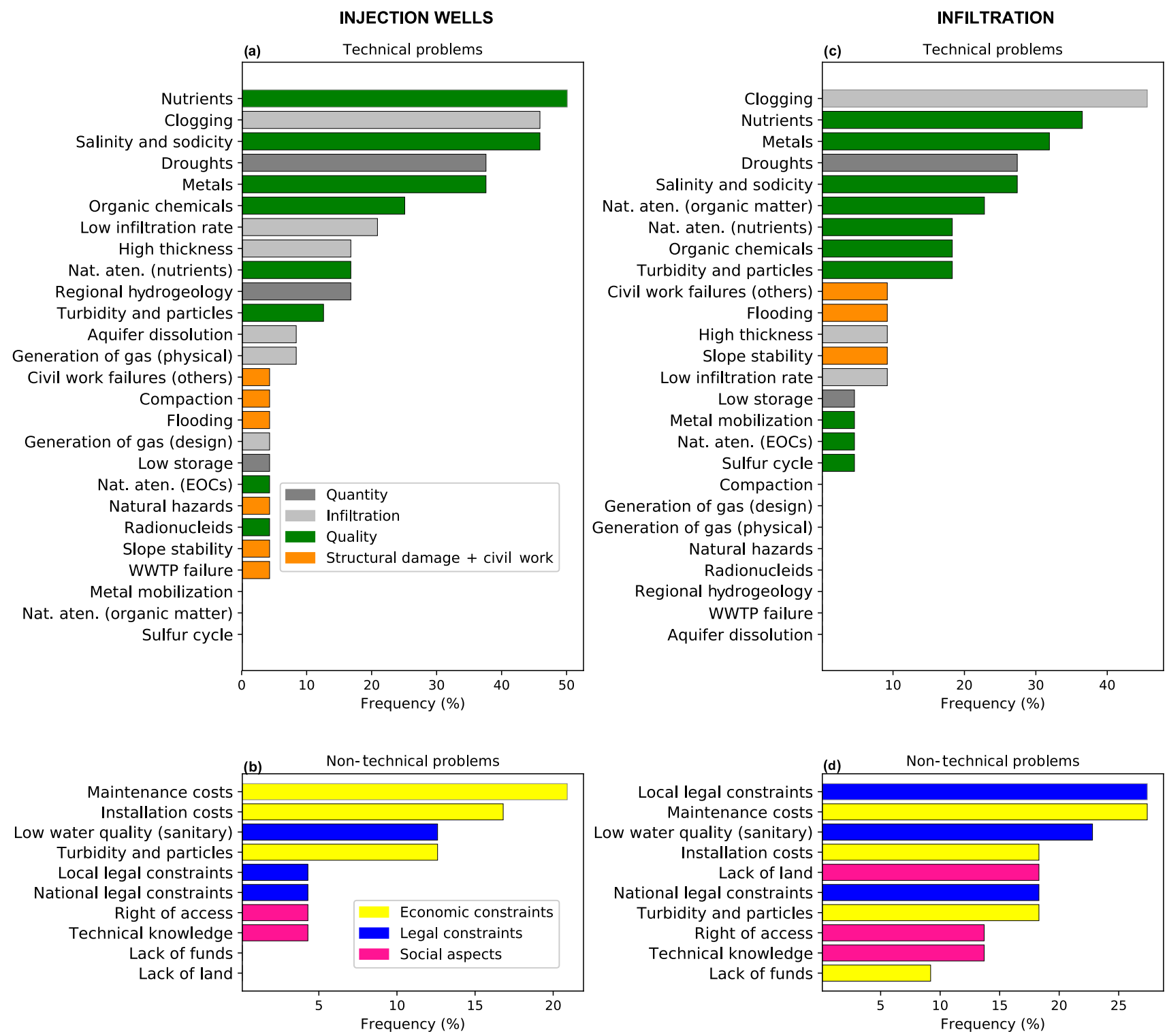

Figure 1. Sorted list in terms of frequency of appearance of the main problems observed in reviewed facilities of deep well injection and infiltration basin. Problems are classified into categories (four for technical, three for non-technical) that are visualized as colors.

implies the improper functioning of the MAR facility, or the cease of its operation for a prolonged time.

\subsection{Fault tree construction}

The eight categories defined before (technical and nontechnical) are described by a few basic events, giving a total of 65 events (44 technical and 21 non-technical; see Fig. 2). A short definition of all the events can be found in Fig. 2 and in Sect. S2 of the Supplement.

\subsection{Probabilistic representation of the fault tree}

The probabilistic analysis is based on two steps: (1) defining a specific probability for each key event to occur and (2) combining the different events' probabilities, using Boolean algebra, to assign probabilities to the boxes (events) into the one placed immediately above. In this section we illustrate this approach for simplicity and completeness. Additional details about this methodology can be found in Tartakovsky (2007).

For each event, we specify a number of sub-events following two models: (1) if any sub-event occurs, then the event will also occur, thus equivalent to an "OR" operator in Boolean logic; (2) all sub-events must occur for the event to 
Table 1. Events of the fault tree divided by categories for non-technical and technical issues.

\begin{tabular}{|c|c|}
\hline \multirow{4}{*}{ Non-technical } & Legal constraints (LEG): health, urban, environment, construction permits \\
\hline & $\begin{array}{l}\text { Economic constraints (ECO): lack of funds, maintenance or installation costs, } \\
\text { macro and microeconomical problems, etc. }\end{array}$ \\
\hline & $\begin{array}{l}\text { Social unacceptance (SO): health perception, cost perception, effectiveness } \\
\text { perception, etc. }\end{array}$ \\
\hline & $\begin{array}{l}\text { Governance (GOV): coordination between governmental agencies and technical } \\
\text { knowledge about the MAR issues }\end{array}$ \\
\hline \multirow{4}{*}{ Technical } & $\begin{array}{l}\text { Structural damage (SD): damage to the MAR infrastructure due to natural haz- } \\
\text { ards, civil works failure, etc. }\end{array}$ \\
\hline & $\begin{array}{l}\text { Not enough water or quantity (QUAT): low water quality (physical, chemical, } \\
\text { and biological), water scarcity (climate, river regulation, waste water treatment } \\
\text { plant (WWTP) failure, quantity recharged does not reach some target value that } \\
\text { makes it economically feasible ) and clogging (physical, biological, and chem- } \\
\text { ical) water available does not reach the quality standards needed to allow it to } \\
\text { be used in the recharge facility. }\end{array}$ \\
\hline & $\begin{array}{l}\text { Unacceptable water quality (QUAL): problems with natural attenuation (nutri- } \\
\text { ents, organic matter, and emerging organic compounds), metabolites (nitrogen } \\
\text { cycle, other nutrients like } \mathrm{H}_{2} \mathrm{~S} \text {, etc.), and mobilization of metals. The water } \\
\text { finally resulting in the aquifer does not meet some quality standards once it } \\
\text { reaches some sensitive location (river, supply well, wetland, etc.). }\end{array}$ \\
\hline & $\begin{array}{l}\text { Specific targets (ST): failure to achieve targets related to seawater barriers, pro- } \\
\text { tected water bodies, and water levels. Seawater intrusion is not sufficiently con- } \\
\text { tained, a protected water body is reached by polluted water or water levels at } \\
\text { the target surface water bodies (river, spring, wetland) are not reached. }\end{array}$ \\
\hline
\end{tabular}

take place, characteristic of the "AND" operator. Therefore, denoting $E$ as the event and $e_{i}, i=1, \ldots, n$ as the sub-events, the "OR" operators involves

$E($ or $)=U_{1, \ldots, n} e_{i}$

while the "AND" operator results in

$E($ and $)=\bigcap_{1, \ldots, n} e_{i}$

We illustrate this with a simple example (Fig. 3), considering that an issue with either social or political implications increase the probability of having a non-technical MAR failure (which in turn would increase the chance of a general MAR failure). According to the methodology described, we can obtain the probability of the main event (NT), $P[\mathrm{NT}]$, as a function of those of the events $\mathrm{SO}$ (social unacceptance) and PO (lack of political implication).

$$
P(\mathrm{NT})=P(\mathrm{SO} \cup \mathrm{PO})=P(\mathrm{SO})+P(\mathrm{PO})-P(\mathrm{SO} \cap \mathrm{PO})
$$

Notice that the last term in Eq. (3) indicates the product of an intersection; this would also be the case if instead of an "OR" operator we had an "AND" operator, so that in such a case we would have the following formula: $P(\mathrm{NT})=P(\mathrm{SO} \cap \mathrm{PO})$. To compute the probability of the intersection of events, we rely on the concept of conditional probability (e.g., assuming that politics respond directly to social concern), so that

$P(\mathrm{SO} \cap \mathrm{PO})=P(\mathrm{SO}) P(\mathrm{PO} / \mathrm{SO})$.

In the case that SO and PO are independent events, Eq. (4) simplifies to

$P(\mathrm{SO} \cap \mathrm{PO})=P(\mathrm{SO}) P(\mathrm{PO})$.

This system is transferred to the evaluation of basic events in terms of those placed at a lesser level, and so on.

\subsection{Computing the individual probabilities of events and the global system failure}

The next step is to assign probabilities to all basic events at the bottom of the tree, and then build up (bottom-up) to assign probabilities using the Boolean rules above, until the top (full system failure) is reached. As a first step, all events were divided into four categories depending on probability of occurrence (high, medium, low, or no risk). A key point in the assessment of risk is assigning probabilities to each individual basic event, this process being quite challenging. One advantage of the fault tree approach is the possibility of assigning them at several stages of involvement, taking into 


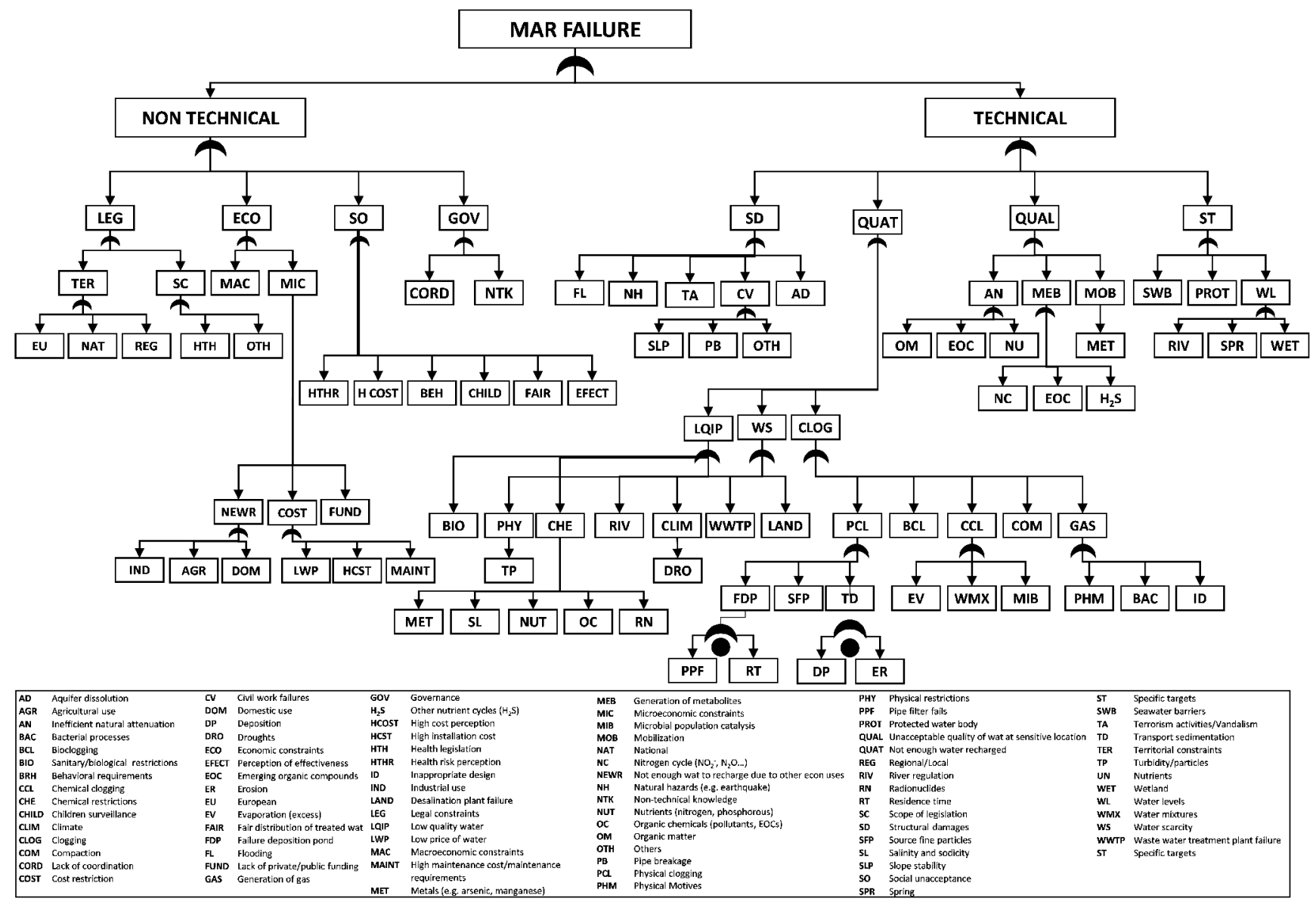

Figure 2. General fault tree for the operational phase.

account a combination of simplicity and relevance. The approach consists of first assigning a (preliminary) value to all basic events; these values may be based on the experience of the managers of the facility or experts. Such values are combined by the Boolean rules to provide a map of critical paths; i.e., events that are up in the tree and that result in a high probability of failure.

The second step would be to devote attention to these significant events and the possibility to correct or reduce their risk in order to reduce the global risk. For those significant events, whose risk contribution is largest, probabilities can be reassigned by using sophisticated approaches, based on, for example, conceptual or numerical modeling and also on changing sampling schemes or putting into operation new observation networks. From these new values, the critical events are re-assessed (including total failure). The process can be repeated as many times as needed, to arrive at an improved value of system failure.

In addition, corrective and preventive measures could be set to reduce the probability for individual events. The full procedure could go on until either economic resources are exhausted or else it is considered that further refinement cannot lead to a significant improvement in the final figure.

We provide an example for the purpose of illustration. Let us assume a surface infiltration pond located in a flood plain. We can start by assigning some probability of the MAR facility being affected by flooding (meaning that operation would have to be discontinued for a long time) using a qualitative approach provided by the facility managers (high, intermediate, low, no risk), maybe including the input of local people that would tell us about potential flooding events that took place during their lifetime. It is very relevant to state that these preliminary numbers should always be on the conservative side, meaning that the less technical the evaluation is the more caution should be included in the actual figures. Here we consider the conservative side as the one providing a larger value of probability of failure than the real one (i.e., from the administration or manager point of view). The second step would use the idea that the facility is located in a 100-year return period flood plain; if we consider the life of the facility of 30 years, and from simple statistics, we can evaluate the probability that flooding occurs during the lifetime as $1-0.99^{30}=0.26$. Now, if this number is excessively 


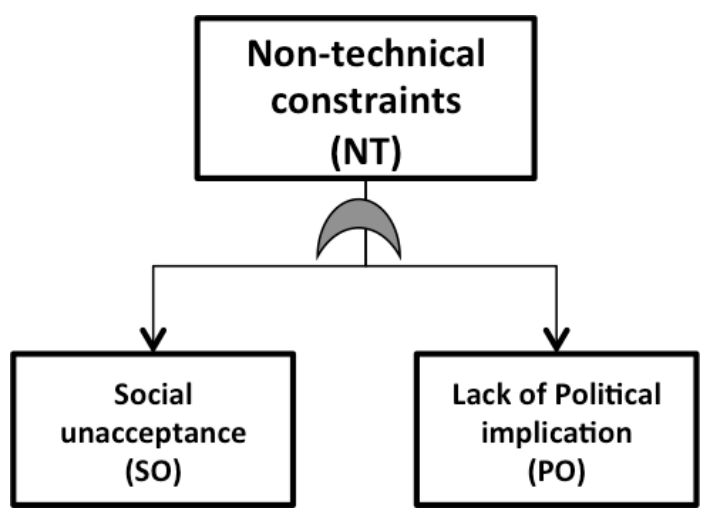

Figure 3. Simplified illustrative case for non-technical constraints involving only sociopolitical constraints. The symbol below the upper event represents an "OR" operator.

high and relevant for the evaluation of overall failure, a further step may include a full hydrological analysis through modeling to re-evaluate the probability of flooding.

Additionally, prevention measures for reducing risk or the damage caused by that risk by using protection works such as embankment construction could be included. Such a measure could then indirectly affect some events (water quality, social acceptance, etc.), leading to the need to continuously update all event risks. This step requires a deep knowledge of the system, and must be done under a local perspective and case by case. As the main goal of this paper is to develop a general methodology to evaluate MAR failure and to compare six sites, this type of analysis is out of the current scope, and we did not perform any detailed analysis of either the risk or its damage reduction of any event.

\section{Description of the field sites}

The PRA-FT analysis was performed for six MAR facilities, located in different parts of the Mediterranean Basin, offering a broad view of risk perception in the whole area. A summary of the characteristics and context of these sites can be found in Table 2.

The first site is located in the Algarve region (south of Portugal). It is based on an infiltration basin constructed in the Rio Seco river bed (Campina de Faro aquifer system). This MAR facility is aimed at improving the water quality of the Campina de Faro aquifer. It was constructed in 2006 (LoboFerreira and Leitão, 2014). The surroundings of the MAR facility are mainly agricultural and one of its main problems is related to water quality due to agriculture diffuse water pollution, mainly by nitrate (Leitão et al., 2017). This site includes other MAR facilities in the Querença-Silves aquifer and Melides watershed, not included in this evaluation.

The second site, Los Arenales, is located in the center of Spain (Castilla y León). The MAR facility is aimed at providing enough water for the development of rural activities in the zone. Besides this, MAR is also aimed at improving the groundwater quality (reducing nitrate concentrations). In this case, the site is an ensemble of different small facilities (infiltration ponds, river bank filtration, and infiltration wells) located in the same aquifer (Los Arenales alluvial aquifer). It started its activity in 2002 and it was expanded in 2003, 2004, and in 2012.

The MAR Llobregat site is located in Catalonia (northeast Spain), in an alluvial aquifer placed some $10 \mathrm{~km}$ southwest of Barcelona city. It is composed of one settling pond and one for infiltration. The recharge water comes from the Llobregat River and the main goal of the facility is to increase the water storage in the aquifer, as well as to improve the quality of the recharged water. A reactive layer was placed at the bottom of the infiltration pond to improve the degradation of both traditional pollutants and emerging organic compounds (e.g., pharmaceuticals; Valhondo et al., 2015). The area surrounding the facility involves agricultural, industrial, and urban uses. It started its activity in 2009.

The induced riverbank filtration scheme along the Serchio river in Sant'Alessio (Lucca, Italy) provides continuous availability of water with good chemical quality for drinking uses to the people of the coastal Tuscany (Rossetto et al., 2015). The MAR scheme is located in a peri-urban or rural area. This facility supplies $15 \mathrm{Mm}^{3}$ year ${ }^{-1}$ and started its activity in the 1960s; it was further improved by building a river weir to increase aquifer storage at the beginning of 2000. The filtration process is so effective that only light treatment using sodium hypochlorite is needed before water is distributed by the local water utility.

The Menashe site is located in Israel. Constructed in 1967, the site includes a settling pond and three infiltration ponds and a canal in which storm water flowing in ephemeral streams are diverted for infiltration in sand dunes overlaying the northern part of the Israeli coastal aquifer. Since 2013, the facility is also used for infiltration of desalinated seawater (1-3\% of production) from the nearby Hadera desalination plant on the Mediterranean coast (Ganot et al., 2017; RonenEliraz et al., 2017). Freshwater is recovered from wells surrounding the infiltration ponds mainly for residential and industrial consumers.

The Malta site is located in the South Malta Coastal Aquifer. The main objective of this site is the implementation of a MAR facility to act as a seawater intrusion barrier and to minimize the salinization risk of the aquifer using a series of infiltration boreholes. The site is located on the coastal margin of a predominantly agricultural region in a limestone aquifer. The activity started in 2016 , and is considered as a pilot site to guide the future implementation of MAR in the Maltese islands. 
Table 2. Events of the fault tree divided by categories for non-technical and technical issues.

\begin{tabular}{|c|c|c|c|c|c|c|}
\hline Site & Algarve & Los Arenales & Llobregat & Serchio & Menashe & Malta \\
\hline Location & $\begin{array}{l}\text { Algarve (Por- } \\
\text { tugal) }\end{array}$ & $\begin{array}{l}\text { Los Arenales } \\
\text { (Spain) }\end{array}$ & $\begin{array}{l}\text { Sant Vicenç } \\
\text { dels Horts } \\
\text { (Spain) }\end{array}$ & $\begin{array}{l}\text { Lucca } \\
\text { (Italy) }\end{array}$ & $\begin{array}{l}\text { Menashe } \\
\text { (Israel) }\end{array}$ & $\begin{array}{l}\text { south Malta } \\
\text { (Malta) }\end{array}$ \\
\hline Type of recharge & $\begin{array}{l}\text { Surface infil- } \\
\text { tration basins } \\
\text { and } \\
\text { large wells }\end{array}$ & $\begin{array}{l}\text { Surface infil- } \\
\text { tration (chan- } \\
\text { nels, ditches, } \\
\text { ponds) } \\
\text { and wells }\end{array}$ & $\begin{array}{l}\text { Surface infil- } \\
\text { tration basin }\end{array}$ & $\begin{array}{l}\text { Induced } \\
\text { riverbank } \\
\text { filtration }\end{array}$ & $\begin{array}{l}\text { Surface } \\
\text { infiltration } \\
\text { basin }\end{array}$ & Deep wells \\
\hline Source of recharge water & $\begin{array}{l}\text { River water } \\
\text { and WWTP } \\
\text { water }\end{array}$ & River water & River water & River water & $\begin{array}{l}\text { Storm water } \\
\text { and } \\
\text { desalinated } \\
\text { seawater }\end{array}$ & $\begin{array}{l}\text { WWTP } \\
\text { water }\end{array}$ \\
\hline Use of recharged water & $\begin{array}{l}\text { Improving } \\
\text { aquifer water } \\
\text { quality and } \\
\text { aquifer } \\
\text { storage to pre- } \\
\text { vent seawater } \\
\text { intrusion }\end{array}$ & Agriculture & $\begin{array}{l}\text { Improve } \\
\text { aquifer } \\
\text { quantity and } \\
\text { quality }\end{array}$ & $\begin{array}{l}\text { Increase } \\
\text { groundwater } \\
\text { availability } \\
\text { and quality } \\
\text { for drinking } \\
\text { water supply }\end{array}$ & $\begin{array}{l}\text { Store excess } \\
\text { of storm and } \\
\text { desalinated } \\
\text { water }\end{array}$ & $\begin{array}{l}\text { Coastal bar- } \\
\text { rier } \\
\text { for seawater } \\
\text { intrusion, in- } \\
\text { crease water } \\
\text { quantity and } \\
\text { quality }\end{array}$ \\
\hline Surrounding & Farmland & Farmland & $\begin{array}{l}\text { Farmland } \\
\text { and } \\
\text { industrial } \\
\text { park }\end{array}$ & $\begin{array}{l}\text { Farmland/ } \\
\text { peri-urban } \\
\text { areas }\end{array}$ & $\begin{array}{l}\text { Farmland, } \\
\text { industrial, } \\
\text { and } \\
\text { urban areas }\end{array}$ & $\begin{array}{l}\text { Coastal zone, } \\
\text { farmland }\end{array}$ \\
\hline Aquifer geology & Alluvial & $\begin{array}{l}\text { Aeolian } \\
\text { sandy }\end{array}$ & Alluvial & $\begin{array}{l}\text { Sand and } \\
\text { gravel } \\
\text { alluvial }\end{array}$ & $\begin{array}{l}\text { Interlayered } \\
\text { sands } \\
\text { calcareous- } \\
\text { sandstone } \\
\text { and clays }\end{array}$ & $\begin{array}{l}\text { Coastal, } \\
\text { floating-lens } \\
\text { aquifer }\end{array}$ \\
\hline Supporting/managing institute & $\begin{array}{l}\text { Águas do Al- } \\
\text { garve }\end{array}$ & $\begin{array}{l}\text { Spanish Min- } \\
\text { istry of Agri- } \\
\text { culture, Fish- } \\
\text { ing, Food } \\
\text { and Environ- } \\
\text { ment }\end{array}$ & $\begin{array}{l}\text { Catalan Wa- } \\
\text { ter Agency }\end{array}$ & GEAL spa & $\begin{array}{l}\text { Mekorot } \\
\text { National } \\
\text { Water } \\
\text { Company }\end{array}$ & $\begin{array}{l}\text { Malta Re- } \\
\text { sources } \\
\text { Authority } \\
\text { and } \\
\text { Water Ser- } \\
\text { vices Corpo- } \\
\text { ration }\end{array}$ \\
\hline Social setup & $\begin{array}{l}\text { Farmers } \\
\text { irrigation } \\
\text { associations } \\
\text { willing } \\
\text { to contribute } \\
\text { to financing } \\
\text { MAR }\end{array}$ & $\begin{array}{l}\text { Farmers, } \\
\text { small indus- } \\
\text { try presence } \\
\text { and } \\
\text { local public } \\
\text { administrations }\end{array}$ & $\begin{array}{l}\text { Water Users } \\
\text { Community } \\
\text { (Farmers } \\
\text { and industry } \\
\text { presence) }\end{array}$ & $\begin{array}{l}\text { Drinking } \\
\text { water needed } \\
\text { for the town } \\
\text { of } \\
\text { Pisa, Lucca, } \\
\text { and Livorno } \\
\text { (Italy) }\end{array}$ & $\begin{array}{l}\text { Pressure } \\
\text { on land-use } \\
\text { from indus- } \\
\text { trial sector } \\
\text { versus water } \\
\text { sector }\end{array}$ & $\begin{array}{l}\text { Coastal } \\
\text { barrier for } \\
\text { seawater } \\
\text { intrusion in } \\
\text { agricultural } \\
\text { region }\end{array}$ \\
\hline
\end{tabular}

\section{Probability assignment and global risk computation}

\subsection{Risk probability assignment}

The probabilities for the basic events were defined by the personnel in charge of each MAR facility, according to their own experience (expert criteria). These values reflected the prob- ability that the MAR facility failed due to the occurrence of one of these basic events, considering a time period of approximately 2-6 years. The expert criteria included values of each risk category (high, medium, and low risk) for each fault tree basic event. Then the users filled a qualitative questionnaire, where for each basic event one of the four risk categories had to be chosen. This questionnaire reproduced the 
same events of the fault tree but sorted as a list at different levels. Then, the qualitative answers were translated to absolute values of probabilities using the values of the expert criteria and the rules of Boolean algebra.

\subsection{Global risk computation: MAR-RISKAPP}

Once the probability values for each basic event were defined, and the questionnaires filled, global risk values for each facility were computed using a visual application tool, the MAR-RISKAPP. This tool was carried out in a friendly interface, aimed at being used by the managers of MAR facilities worldwide. The tool allows the user to assign one of the four risk categories to each basic event. A value of probability is then assigned by default to each event and category. The user can then manually modify each one of the probability values to keep updating the values of the full tree. The global probability of system failure is then computed internally.

The MAR-RISKAPP is an open-source application which can be downloaded from the website (http://marsol.eu/ 35-0-Results.html, last access: 6 June 2018). The main flowchart of the app is shown in Fig. 4 and the manual of the app is summarized in Sect. S3 of the Supplement.

\section{Results and discussion}

\subsection{Comparison of risk probabilities defined by expert criteria}

As a first step, we have compared the differences between the values provided by the facility managers, internally incorporating personal knowledge and technical expertise, for the six sites. Notice that this way we compare the "perception of risk" rather than actual risk. The results, presented as a box plot of all the values reported by categories, showed that the larger values of risk perceived corresponded to events classified as non-technical (Fig. 5). The risk values (in probability terms) in decreasing order were: legal constraints, social aspects, and economic constraints. On the other hand, for the technical part, the order was (also in decreasing order): water quantity, structural damage, and water quality. Therefore, the perception of risk of the managers of each MAR facility, based on their knowledge and experience, indicates that non-technical aspects are critical and can eventually lead to the facility failing to operate; it might imply that during operation and when the facility has been located in a technically appropriate site, much more uncertainty is expected bz non-technical issues than by technical ones. Legislation was the category with highest risk perception. In general terms, this is explained by the lack of or extremely new (such as in Italy with Decreto Ministeriale 100/2016) pieces of specific legislation about MAR at the European level. The existing European water directives only provide little guidance for authorizing aquifer recharge schemes (Hochstrat et al.,
2010). Consequently, MAR regulation is covered by different institutions and authorities dealing with water, environmental, and health legislation. For example, in Menashe, the water recharged is to be used as drinking water, therefore the health legislation risk exceeds other associated legal risks. On the other hand, in Algarve, the infiltration zone is inside a nitrate vulnerable zone and a coastal nature reserve, leading to highest environmental regulation risks. In the Malta case, highest legal risks are associated to the potential for saline intrusion.

The following category in terms of risk perception was social aspects, related to the unacceptance of recharge technology by society. We believe that this could be related, again, to the lack of a concise legislation, which creates social uncertainty and a lack of awareness. We observed that social issues were mostly present in those sites with strong political implications, where the public administrations or the agricultural users participate in the management (and even in the construction) of the MAR facility, such as Llobregat, Los Arenales, or Malta.

Regarding the water quantity aspects, their relatively high importance could be explained because the sites are located in a Mediterranean climate (floods and droughts are typical in such environments). Besides this, it is related to the infiltration capacity of the system (especially in infiltration basins like Los Arenales and Llobregat) and this is traditionally one of the main technical issues in MAR (Fig. 1). Nevertheless, in general terms, infiltration capacity of the system was not an important category in risk perception, probably because the sites were located in highly permeable zones, suitable for recharge, and most of the sites included actions in their maintenance tasks to minimize its importance.

The risk perception on the quality issues could include the following topics: recovered-water use and water source. For example, Serchio recharged water is used as drinking water; consequently, quality plays a higher role than, for example, in Malta, where water is used as a water barrier to salt intrusion. On the other hand, quality is also important in sites where quality aspects existed independently of recharge, like Arenales (high presence of nitrate in groundwater due to farming activity in the zone; see San-Sebastián et al., 2018) and Llobregat (quality problems related to industrial and urban activities; see Valhondo et al., 2015).

This structural damages category is non-negligible, but in general it is not perceived as critical, probably because we are considering sites already in operation. This issue could be more significant in the design process of a facility, and also during construction.

\subsection{Comparing risk in the different sites}

The risk values for the six sites studied are summarized in Fig. 6. We can observe that the total risk of three of the six sites (Los Arenales, Algarve, and Llobregat) is very large (equal or above 0.9), indicating that facility failure is almost 


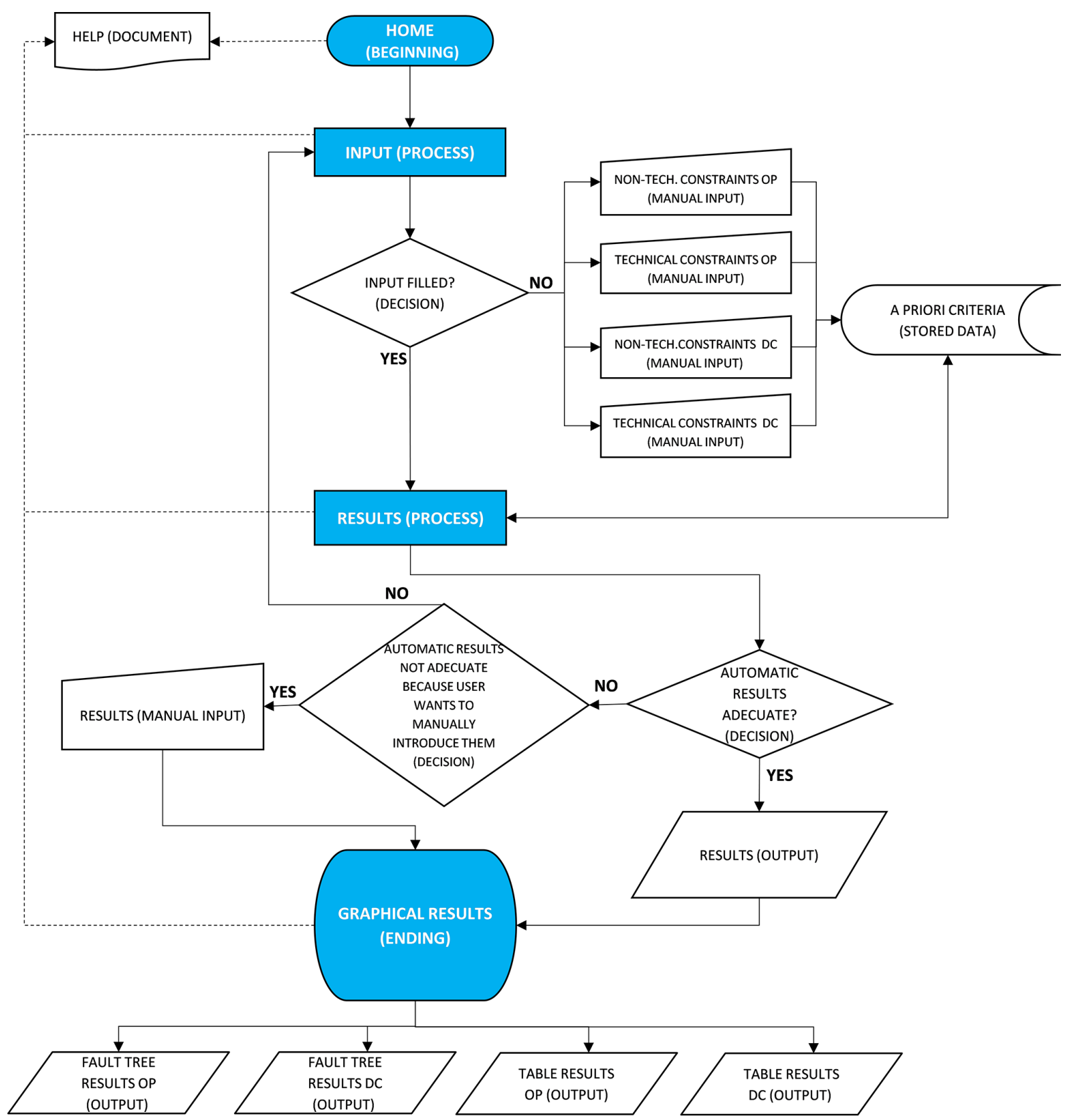

Figure 4. Flowchart for the main program of the MAR-RISKAPP.

certain during a 2- to 6-year period. This indicates that the system will most probably have to discontinue operation; however, this does not imply that the system cannot be put back into operation again. Lack of specific legislation, economic constraints, social issues, and quantitative aspects are the most probable cause for failure of these three facilities. Regarding water quantity being a potential cause of failure, the fact that all three sites involve surface infiltration with river water promote the importance of quantity and clogging aspects, as Mediterranean rivers display low flows and high suspended solid content. Besides this, these three sites are quite young (around 10 years old), which could imply that the are not completely optimized.

On the other hand, Serchio, Menashe, and Malta have lower risk values $(0.18,0.29$, and 0.75 , respectively). The cases of Serchio and Menashe can be explained because they are the oldest sites, with large experience in the operation of the facilities (therefore lowering the technical risks to below 0.1). Furthermore, the hydraulic characteristics of Serchio added to the riverbed recharging area produces negligible effects of clogging. The case of Menashe is justified by the use of desalinated and storm water for recharge. In the 

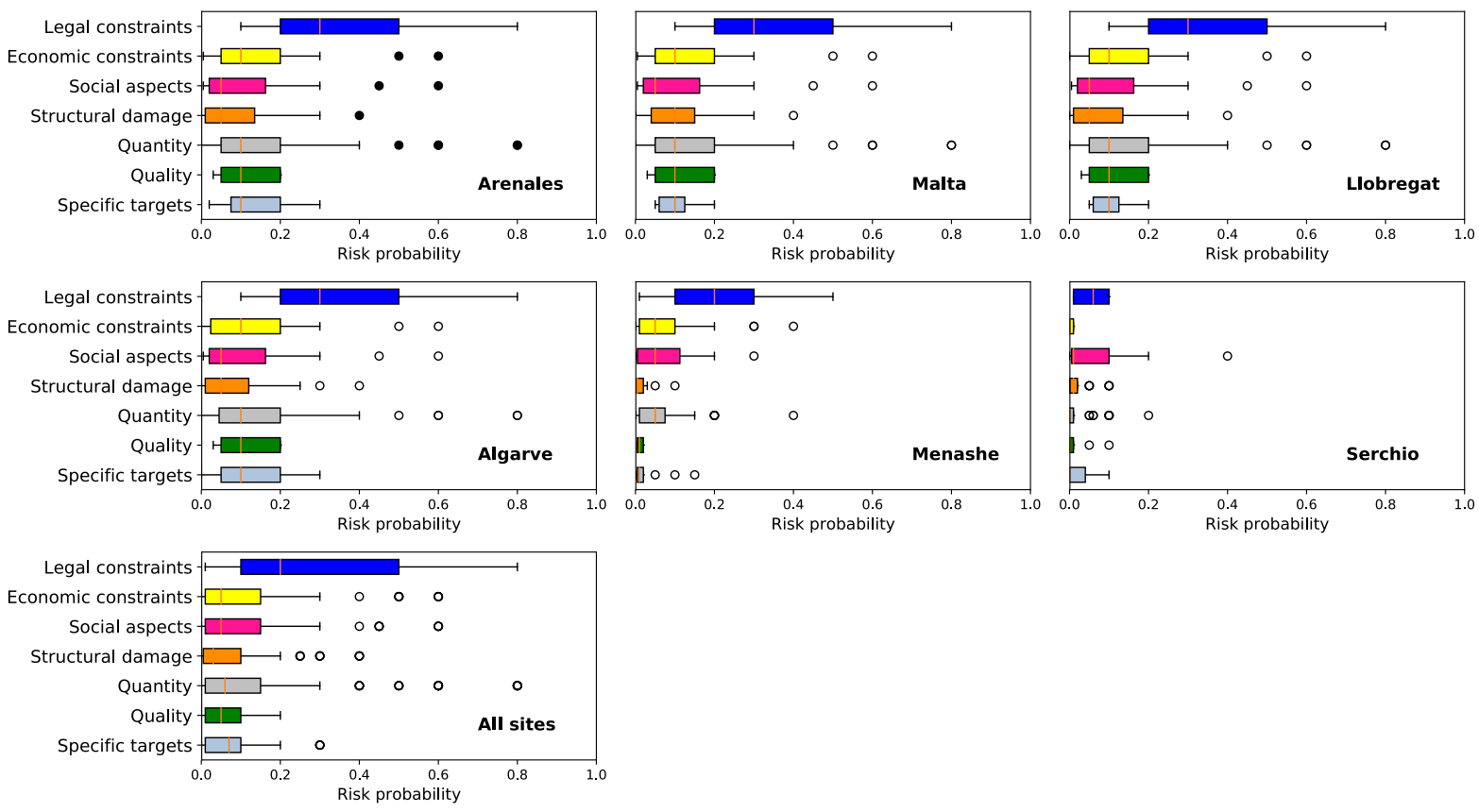

Figure 5. Distribution of the expert criteria by category and for the three levels (low, medium, high) grouped by categories.

case of Malta, the low risk value could be just perception, based on the fact that the site just recently started operation.

From all technical constrains, the one with the highest risk is related to water quantity. Half of the sites showed significant risk in terms of quantity, somewhat correlated with the sources of water for infiltration (being largest for those relying on surface water: Algarve, Llobregat, and Arenales). In the case of Malta, quantitative problems are related to the need to produce good quality water from wastewater. The Algarve site is a particular case as its aim is to improve groundwater quality with recharging water from a nonperennial stream (surface water flows only 60-70 days per year). Therefore, the lack of water is already considered in the MAR scheme. In terms of quality, again, the three sites supplied with river water are those showing the highest risks. That could respond to the variability in river water quality along the year. The geological and hydrogeological context does not seem to have any effect on the technical risk values despite it being very significant to define the site location to construct the MAR facilities.

Individually, the main risk issues for the technical issues in the Llobregat site were quantitative aspects, mainly clogging due to fine particles (probability $=0.4$ ) and recharge water turbidity (0.4). The non-technical issues were mostly related to social aspects: lack of coordination amongst stake holders (0.4), children surveillance (0.3), and fair distribution of water (0.3). These three social aspects are aligned with the indicators of acceptance of Mankad and Walton (2015). For the Algarve site, the technical issues were mostly potential flooding (0.3), droughts (0.3), specific target (protected water body) (0.3), vandalism or terrorism (0.2), and clogging (0.2). Non-technical issues were mainly related to regional or local legislation (0.3). Non-technical issues for the Menashe site include domestic water use (0.15), perception of effectiveness (0.05), and high cost perception (0.05); for the technical ones, terrorism activities (0.02) and clogging due to compaction (0.02) were the most significant.

The Serchio site had the lack of knowledge on MAR activities (0.05) and health legislation (0.01) for the non-technical main risks. For the technical aspects, quality aspects related to organic compounds were the largest (0.01). The Los Arenales site had very large risk values associated with national (0.6), regional or local (0.8), and other legislation (0.5); agricultural water use (0.6); and fair distribution of water (0.45); the most significant technical issues were flooding $(0.1)$, nutrients in the recharge water $(0.5)$, droughts $(0.8)$, generation of gas - physical clogging (0.2), nitrogen metabolites $(0.2)$, river (0.1), and wetland water levels (0.2). The Malta site identified the European legislation (0.2) and lack of coordination (0.1) as the main non-technical risk drivers. For the technical aspects, largest risks included pipe breakage $(0.05)$ and different specific targets: seawater barriers (0.4), protected water body (0.1), and groundwater levels (0.3).

The risk values obtained are mostly correlated to the expert criteria values. This correlation was evaluated by applying a Pearson product-moment correlation between the expert criteria basic events (considered the medium risk values) and the results basic events for each site. There were in total 65 basic events, leaving a total of 63 degrees of freedom and considering a $p$ value of 0.05 as the confidence limit of ac- 


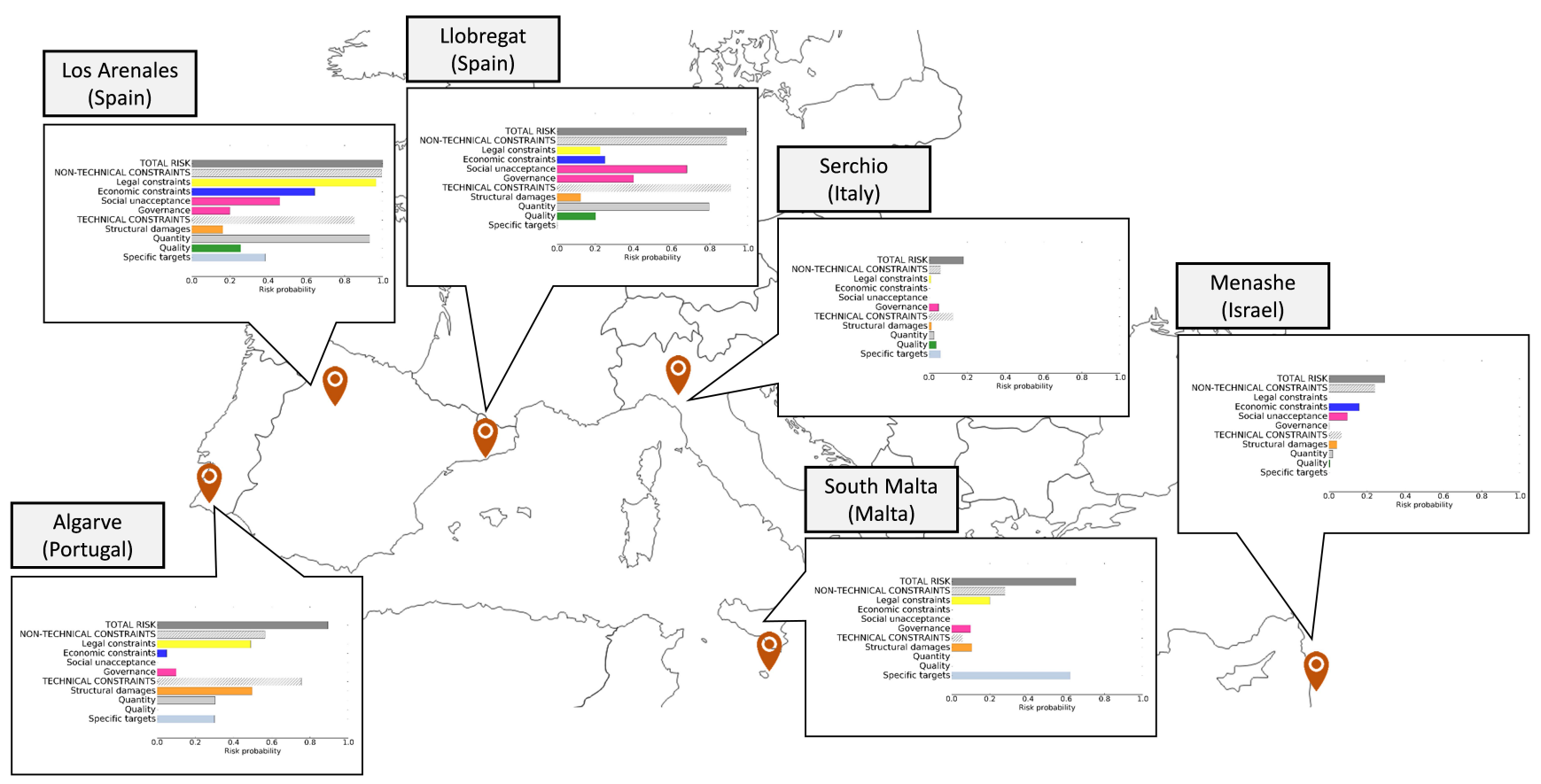

Figure 6. Risk in the different MAR sites.

ceptance. It was observed that, in general terms, a correlation between the perception of risk (expert criteria) and actual risk (results) existed. This mainly means that the facility managers know the main problems of the sites and thus define the expert criteria values accordingly. This indicates the relevance of using such a simplified method for preliminary risk assessment.

The actual results of the analyses showed correlation (in terms of $p$ value) in the cases of Llobregat $(p=0.026)$, Los Arenales $\left(7.38 \times 10^{-13}\right)$, Malta $\left(3.2 \times 10^{-7}\right)$, Algarve (0.048), and Serchio $\left(2.39 \times 10^{-12}\right)$, while for Menashe site (0.6), that correlation could not be observed. Looking at the data, Menashe expert criteria values lack absolute zero values ( 0 from 65); however, the result values obtained show a high proportion of NO RISK (risk $=0$ ) values (52 from the total of 65). Then the difference between both Expert criteria and Results become apparent, probably related to the knowledge of the personnel in charge of the Menashe site and their confidence in the lack of risk of their operations. A significant point to make is that there is a discrepancy between the literature review and our results. The most significant events leading to failure that we found in the literature were the technical ones, rather than the non-technical (recall Fig. 1). Our analysis on the six Mediterranean sites concluded the opposite. We attribute this discrepancy to a bias in the scientific literature towards technical issues. We could not find information on MAR facilities failure in journals devoted to social or economic sciences.

\section{Conclusions}

In this paper, we have developed a methodology to evaluate the risk of failure of managed aquifer recharge (MAR) facilities, and we have applied it to six different facilities located in the Mediterranean Basin. The methodology was based on the development of a probabilistic risk assessment based on fault trees. The PRA-FT methodology considered different categories affecting the operation of the facility. We further defined 65 basic events that individually or properly combined can produce global failure of the MAR facility. These events were compiled from a literature review of 51 MAR facilities, and then extended with the results of the European project MARSOL ("Demonstrating Managed Aquifer Recharge as a Solution to Water Scarcity and Drought").

The methodology consists of providing probability values to all basic events to take place in a window of time. Then, events at an upper level are computed from Boolean algebra until the top of the tree (total failure) is quantified. The initial step is to provide values based on expert criteria, assigned from the four risk categories: low, medium, high, and no risk. All values can be updated sequentially and probabilities are recalculated, until the values converge. The basic events include both technical and non-technical events.

A full preliminary (without updating) assessment of risk was developed for six sites located in the Mediterranean Basin. It was found that the non-technical aspects can be the most significant ones, contributing more than the technical issues to the overall assessment of risk. This is despite the fact that we are only considering facilities under operation, 
so that some issues are supposed to be already resolved. In short, the combination of legal, social, and economic factors can provide a really strong contribution to global risk. Consequently, future risk works based in managed aquifer recharge should consider how to lower risks by non-technical factors.

All events considered, we found that in the facilities analyzed, the major contributors to overall risk were the following: in decreasing order of importance, quantity issues (0.35), legal constraints $(0.32)$, specific targets $(0.23)$, social aspects (0.21), economic constraints (0.18), structural damages $(0.16)$, governance $(0.14)$, and quality $(0.09)$. In particular, when the recharge water is supplied by a river, quantity aspects increase their relevance, due to the uncertainty in the current and future potential capacity for supplying in a dry and variable climate such as the Mediterranean Basin.

The site-specific results were obtained from a questionnaire, and so they provide "perception of risk" rather than "actual risk", and thus could and should be amended. The PRA-FT methodology allows us to now concentrate on the specific issues that individually, or combined, lead to the largest probability of failure, and concentrate the efforts in updating such values by means of detailed evaluations or specific projects of rehabilitation. The system can go on using any number of re-evaluations until an acceptable value or either until no further improvement can be obtained.

Regarding the results on perception of risk for the individual sites, it was surprising to get three of them (Los Arenales, Algarve, and Llobregat) above 0.90 in a 2- to 6-year period. The main contributors to failure were related to non-technical reasons and to quantity aspects. Actually, in recent years all three facilities had to discontinue operations at least one, indicating that the evaluations provide reasonable estimations. The Malta site is a very recent one, with little history behind, and this makes not possible to evaluate whether the perception of risk of $75 \%$ is high or low.

On the other hand, the risks perceived for the other two sites, Serchio and Menashe, can be considered low (18 and $29 \%$, respectively). A potential reason is that they are the oldest facilities, so experience has been accumulated for decades. Also, the facilities have been able to adapt to evolving regulations (both local and at the European levels). In both cases, low risk values correlated also with low perception of availability risk (mainly related to clogging), due to the mechanisms and sources of recharge water in both cases (river bank filtration in Serchio and desalinated and storm water in Menashe).

Data availability. All data are available from the corresponding author upon request.

Supplement. The supplement related to this article is available online at: https://doi.org/10.5194/hess-22-3213-2018-supplement.
Competing interests. The authors declare that they have no conflict of interest.

Acknowledgements. Financial support was provided by the project MARSOL grant agreement no. 619120, FP7-ENV2013-WATER-INNO-DEMO, by the European Union, project ACWAPUR, PCIN-2015-239, project INDEMNE, CGL201569768-R (MINECO/FEDER) by the Spanish government. Arnau Canelles thanks to the Government of Catalonia for financial support (AGAUR, FI2016). Rudy Rossetto also thanks the technical support of GEAL S.p.a.

Edited by: Alberto Guadagnini

Reviewed by: YongCheol Kim, Aronne Dell'Oca, and Giorgio Ghiglieri

\section{References}

Aiken, G. and Kuniansky, E.: Mobilization of arsenic and other trace elements during aquifer storage and recovery, southwest Florida, US Geological Survey, 47-50, 2002.

Alazard, M., Boisson, A., Maréchal, J.-C., Perrin, J., Dewandel, B., Schwarz, T., Pettenati, M., Picot-Colbeaux, G., Kloppman, W., and Ahmed, S.: Investigation of recharge dynamics and flow paths in a fractured crystalline aquifer in semi-arid India using borehole logs: implications for managed aquifer recharge, Hydrogeol. J., 24, 35-57, https://doi.org/10.1007/s10040-0151323-5, 2016.

Asano, T. and Cotruvo, J. A.: Groundwater recharge with reclaimed municipal wastewater: Health and regulatory considerations, Water Res., 38, 1941-1951, https://doi.org/10.1016/j.watres.2004.01.023, 2004.

Assmuth, T., Simola, A., Pitkänen, T., Lyytimäki, J., and Huttula, T.: Integrated frameworks for assessing and managing health risks in the context of managed aquifer recharge with river water, Integr. Environ. Asses., 12, 160-173, https://doi.org/10.1002/ieam.1660, 2016.

Ayuso-Gabella, N., Page, D., Masciopinto, C., Aharoni, A., Salgot, M., and Wintgens, T.: Quantifying the effect of Managed Aquifer Recharge on the microbiological human health risks of irrigating crops with recycled water, Agr. Water Manage., 99, 93-102, https://doi.org/10.1016/j.agwat.2011.07.014, 2011.

Bedford, T. and Cooke, R.: Probabilistic Risk Analysis: Foundations and Methods, Cambridge University Press, New York, 2003.

Bhusari, V., Katpatal, Y. B., and Kundal, P.: An innovative artificial recharge system to enhance groundwater storage in basaltic terrain: example from Maharashtra, India, Hydrogeol. J., 24, 12731286, https://doi.org/10.1007/s10040-016-1387-x, 2016.

Bolster, D., Barahona, M., Dentz, M., Fernandez-Garcia, D., Sanchez-Vila, X., Trinchero, P., Valhondo, C., and Tartakovsky, D. M.: Probabilistic risk analysis of groundwater remediation strategies, Water Resour. Res., 45, 1-10, https://doi.org/10.1029/2008WR007551, 2009.

Bouwer, H.: Artificial recharge of groundwater: Hydrogeology and engineering, Hydrogeol. J., 10, 121-142, https://doi.org/10.1007/s10040-001-0182-4, 2002. 
Bouwer, H.: Environment Integrated water management for the 21st century : Problems and Solutions, J. Irrig. Drain. E., $128, \quad 118-152, \quad$ https://doi.org/10.1061/(ASCE)07339437(2002)128:4(193), 2003.

Chaoka, R., Alemaw, B., and Molwalelfhe, L.: Investigating the causes of water-well failure in the Gaotlhobogwe wellfield in southeast Botswana, J. Appl. Sci. Environ. Manag., 10, 59-65, 2006.

De Barros, F. P., Bolster, D., Sanchez-Vila, X., and Nowak, W.: A divide and conquer approach to cope with uncertainty, human health risk, and decision making in contaminant hydrology, Water Resour. Res., 47, W05508, https://doi.org/10.1029/2010WR009954, 2011.

De Barros, F. P., Fernàndez-Garcia, D., Bolster, D., and SanchezVila, X.: A risk-based probabilistic framework to estimate the endpoint of remediation: Concentration rebound by ratelimited mass transfer, Water Resour. Res., 49, 1929-1942, https://doi.org/10.1002/wrcr.20171, 2013.

Dillon, P.: Future management of aquifer recharge, Hydrogeol. J., 13, 313-316, https://doi.org/10.1007/s10040-004-0413-6, 2005.

Dillon, P., Pavelic, P., Page, D., Beringen, H., and Ward, J.: Managed aquifer recharge : An Introduction, Tech. Rep. 13, National water Comission, Canberra, 2009.

Dillon, P., Vanderzalm, J., Page, D., Barry, K., Gonzalez, D., Muthukaruppan, M., and Hudson, M.: Analysis of ASR clogging investigations at three Australian ASR sites in a Bayesian context, Water, 8, 442, https://doi.org/10.3390/w8100442, 2016.

European Community: Directive 2000/60/EC of the European Parliament and of the Council of 23 October 2000 establishing a framework for Community action in the field of water policy, Official Journal of the European Parliament, L327, 1-82, https://doi.org/10.1039/ap9842100196, 2000.

Fader, M., Shi, S., von Bloh, W., Bondeau, A., and Cramer, W.: Mediterranean irrigation under climate change: more efficient irrigation needed to compensate for increases in irrigation water requirements, Hydrol. Earth Syst. Sci., 20, 953-973, https://doi.org/10.5194/hess-20-953-2016, 2016.

Flint, A. L. and Ellett, K. M.: The Role of the Unsaturated Zone in Artificial Recharge at San Gorgonio Pass, California, Vadose Zone J., 3, 763-774, https://doi.org/10.2136/vzj2005.0222, 2005.

Gale, I. N., Macdonald, D. M. J., Calow, R. C., Neumann, I., Moench, M., Kulkarni, H., Mudrakartha, S., and Palanisami, K.: Managed Aquifer Recharge : an assessment of its role and effectiveness in watershed management, Tech. rep., British Geological Survey, Nottingham, 2006.

Ganot, Y., Holtzman, R., Weisbrod, N., Nitzan, I., Katz, Y., and Kurtzman, D.: Monitoring and modeling infiltrationrecharge dynamics of managed aquifer recharge with desalinated seawater, Hydrol. Earth Syst. Sci., 21, 4479-4493, https://doi.org/10.5194/hess-21-4479-2017, 2017.

Hochstrat, R., Wintgens, T., Kazner, C., Jeffrey, P., Jefferson, B., and Melin, T.: Managed aquifer recharge with reclaimed water: Approaches to a European guidance framework, Water Sci. Technol., 62, 1265-1273, https://doi.org/10.2166/wst.2010.386, 2010.

Izbicki, B. J. A., Metzger, L. F., Mcpherson, K. R., Everett, R. R., and Benett, G. L.: ources of High-Chloride Water to Wells, Eastern San Joaquin Groundwater Subbasin, California. Tech. rep., U.S. Geological, Survey, New York, available at: https:// pubs.usgs.gov/of/2006/1309/pdf/ofr2006-1309.pdf (last access: 6 June 2018), 2006.

Ji, H. and Lee, S.-I.: Comparison of Potential Risk on Two Managed Aquifer Recharge Sites from River Basin, Water, 9, 674, https://doi.org/10.3390/w9090674, 2017.

Ji, H. W. and Lee, S. I.: Assessment of risk due to chemicals transferred in a watershed: A case of an aquifer storage transfer and recovery site, Water, 8, 242, https://doi.org/10.3390/w8060242, 2016.

Juntunen, J., Meriläinen, P., and Simola, A.: Public health and economic risk assessment of waterborne contaminants and pathogens in Finland, Sci. Total Environ., 599-600, 873-882, https://doi.org/10.1016/j.scitotenv.2017.05.007, 2017.

Jurado, A., De Gaspari, F., Vilarrasa, V., Bolster, D., SánchezVila, X., Fernàndez-Garcia, D., and Tartakovsky, D. M.: Probabilistic analysis of groundwater-related risks at subsurface excavation sites, Eng. Geol., 125, 35-44, https://doi.org/10.1016/j.enggeo.2011.10.015, 2012.

Leitão, T., Lobo-Ferreira, J., Martins, T., Oliveira, M. M., and Henriques, M.: Demonstrating Managed Aquifer Recharge as a Solution to Water Scarcity and Drought - MAR to Improve the Groundwater Status in South Portugal, Tech. Rep. 619120, European Commission, 2017.

Leviston, Z., Nancarrow, B. E., Tucker, D. I., and Porter, N. B.: Predicting Community Behaviour : Indirect Potable Reuse of Wastewater through Managed Aquifer Recharge, Land and Water Science Report 2906, 2006.

Lobo-Ferreira, J. P. L. and Leitão, T. E.: Demonstrating managed aquifer recharge as a solution for climate change adaptation; results from Gabardine project and ASEMWaterNet coordination action in the Algarve region (Portugal), Acque Sotterranee Testo Stampato, 3, 15, https://doi.org/10.7343/as-080-14-0106, 2014.

Maliva, R. G. and Missimer, T. M.: Arid Lands Water Evaluation and Management, vol. 3, Springer, Berlin Heidelberg, https://doi.org/10.1007/978-3-540-88258-9, 2012.

Mankad, A. and Walton, A.: Accepting managed aquifer recharge of urban storm water reuse: The role of policyrelated factors, Water Resour. Res., 51, 9696-9707, https://doi.org/10.1002/2015WR017633, 2015.

Masetti, M., Pedretti, D., Sorichetta, A., Stevenazzi, S., and Bacci, F.: Impact of a Storm-Water Infiltration Basin on the Recharge Dynamics in a Highly Permeable Aquifer, Water Resour. Manag., 30, 149-165, https://doi.org/10.1007/s11269-0151151-3, 2016.

Murray, R. and Ravenscroft, P.: Strategy and Guideline Development for National Groundwater Planning Requirements. Potential Artificial Recharge Schemes: Planning for Implementation, Tech. rep., Department of Water Affairs, Pretoria, 2010.

Nandha, M., Berry, M., Jefferson, B., and Jeffrey, P.: Risk assessment frameworks for MAR schemes in the UK, Environ. Earth Sci., 73, 7747-7757, https://doi.org/10.1007/s12665-014-3399y, 2015.

Navarro-Ortega, A., Acuña, V., Batalla, R. J., Blasco, J., Conde, C., Elorza, F. J., Elosegi, A., Francés, F., La-Roca, F., Muñoz, I., Petrovic, M., Picó, Y., Sabater, S., Sanchez-Vila, X., Schuhmacher, M., and Barceló, D.: Assessing and forecasting the impacts of global change on Mediterranean rivers. The SCARCE 
Consolider project on Iberian basins, Environ. Sci. Pollut. R., 19, 918-933, https://doi.org/10.1007/s11356-011-0566-5, 2012.

Pachauri, R., Allen, M., Barros, V., Broome, J., Cramer, W., Christ, R., Church, J., Clarke, L., Dahe, Q., Dasgupta, P., and Dubash, N.: Climate change 2014: synthesis report, Contribution of Working Groups I, II and III to the fifth assessment report of the Intergovernmental Panel on Climate Change, IPCC, https://doi.org/10.1017/CBO9781107415324, 2014.

Page, D., Dillon, P., Vanderzalm, J., Toze, S., Sidhu, J., Barry, K., Levett, K., Kremer, S., and Regel, R.: Risk Assessment of Aquifer Storage Transfer and Recovery with Urban Stormwater for Producing Water of a Potable Quality, Journal of Environment Quality, 39, 2029, https://doi.org/10.2134/jeq2010.0078, 2010.

Petersen, C. E. and Glotzbach, K.: Aquifer Storage and Recovery for the City of Roseville: a Conjunctive Use Pilot Project, Proceedings of the Water Environment Federation, WEFTEC 2005, 8634-8661, https://doi.org/10.2175/193864705783812945, 2005.

Ronen-Eliraz, G., Russak, A., Nitzan, I., Guttman, J., and Kurtzman, D.: Investigating geochemical aspects of managed aquifer recharge by column experiments with alternating desalinated water and groundwater, Sci. Total Environ., 574, 1174-1181, https://doi.org/10.1016/j.scitotenv.2016.09.075, 2017.

Rossetto, R., Barbagli, A., Borsi, I., Mazzanti, G., Vienken, T., and Bonari, E.: Site investigation and design of the monitoring system at the Sant 'Alessio Induced RiverBank Filtration plant (Lucca, Italy), Rendiconti online della Società Geologica Italiana, 35, 248-251, https://doi.org/10.3301/ROL.2015.112, 2015.

San-Sebastián, J., Fernández-Escalante, E., Calero-Gil, R., Carvalho, T., and Rodríguez-Escales, P.: Characterization and benchmarking of seven managed aquifer recharge systems in south-western Europe, Sustain. Water Resour. Manag., 1-23, https://doi.org/10.1007/s40899-018-0232-x, 2018.

Schneider, B. J., Ku, H. F., and Oaksford, E. T.: Hydro-logic effects of artificial-re charge experiments with reclaimed water at east meadow, long island, new york, Tech. rep., U.S. Geological Survey, New York, available at: https://pubs.usgs.gov/wri/1985/ 4323/report.pdf (last access: 6 June 2018), 1987.

Sprenger, C., Hartog, N., Hernández, M., Vilanova, E., Grützmacher, G., Scheibler, F., and Hannappel, S.: Inventory of managed aquifer recharge sites in Europe: historical development, current situation and perspectives, Hydrogeol. J., 25, 1-14, https://doi.org/10.1007/s10040-017-1554-8, 2017.
Stanhill, G., Kurtzman, D., and Rosa, R.: Estimating desalination requirements in semi-arid climates: A Mediterranean case study, Desalination, 355, 118-123, https://doi.org/10.1016/j.desal.2014.10.035, 2015.

Sultana, S. and Ahmed, K. M.: Assessing risk of clogging in community scale managed aquifer recharge sites for drinking water in the coastal plain of south-west Bangladesh, Bangladesh Journal of Scientific Research, 27, 75, https://doi.org/10.3329/bjsr.v27i1.26226, 2016.

Tartakovsky, D. M.: Probabilistic risk analysis in subsurface hydrology, Geophys. Res. Lett., 34, L05404, https://doi.org/10.1029/2007GL029245, 2007.

Toze, S., Bekele, E., Page, D., Sidhu, J., and Shackleton, M.: Use of static Quantitative Microbial Risk Assessment to determine pathogen risks in an unconfined carbonate aquifer used for Managed Aquifer Recharge, Water Res., 44, 1038-1049, https://doi.org/10.1016/j.watres.2009.08.028, 2010.

Tredoux, G. and Cain, J.: The Atlantis Water Resource Management Scheme: 30 years of Artificial Groundwater Recharge, Tech. rep., Department of Water affairs, Cape Town, PRSA 000/00/11609/10 - Activity 17, http://www.artificialrecharge. co.za/casestudies/Atlantis_final_10August2010_reduceddpi.pdf (last access: 6 June 2018), 2010.

Tredoux, G., Van Der Merwe, B., and Peters, I.: Artificial recharge of the windhoek aquifer, namibia: water quality considerations, Boletin Geologico y Minero, 120, 269-278, available at: http: //www.igme.es/Boletin/2009/120_2_2009/269-278.pdf (last access: 6 June 2018), 2009.

Tripathi, M.: In the Face of Changing Climate: Groundwater Development through Artificial Recharge in Hard Rock Terrain of Kumaun Lesser Himalaya, in: Geostatistical and Geospatial Approaches for the Characterization of Natural Resources in the Environment, 937-947, Springer International Publishing, Cham, https://doi.org/10.1007/978-3-319-18663-4_145, 2016.

Valhondo, C., Carrera, J., Ayora, C., Tubau, I., Martinez-Landa, L., Nödler, K., and Licha, T.: Characterizing redox conditions and monitoring attenuation of selected pharmaceuticals during artificial recharge through a reactive layer, Sci. Total Environ., 512513, 240-250, https://doi.org/10.1016/j.scitotenv.2015.01.030, 2015.

Vesely, W. E., Goldberg, F. F., Roberts, N. H., and Haasl, D. F.: Fault Tree Handbook, Tech. Rep. NUREG-0492, available at: https: //www.nrc.gov/docs/ML1007/ML100780465.pdf (last access: 6 June 2018), 1981. 